\title{
First report of Malva vein clearing virus infecting hollyhock in Beijing, China
}

\author{
Meisheng Wei ${ }^{1}(\mathbb{B}$
}

Received: 31 January 2021 / Accepted: 22 July 2021 / Published online: 12 August 2021

(c) Società Italiana di Patologia Vegetale (S.I.Pa.V.) 2021

Keywords Potyvirus $\cdot$ Malva vein clearing virus $\cdot$ Hollyhock

Hollyhock (Alcea rosea) plants showing leaf vein clearing and mottle symptoms were collected in May 2016 from a park in Chaoyang district, Beijing, China. Some aphids were observed on symptomatic leaves. Ten leaf samples were tested using cucumber mosaic virus, hibiscus chlorotic ringspot virus, lettuce mosaic virus, potato virus $\mathrm{Y}$, tomato mosaic virus and potyvirus group ELISA reagents from Agdia Inc., and also used for RNA extractions and reverse transcription (RT)-PCR test. All samples tested negative for these five viruses by ELISA and RT-PCR. Two of ten plants tested potyvirus group positive by antigen coated plate (ACP)-ELISA. To identify the specific potyvirus, RT-PCR was carried out on total RNA from each ACP-ELISA positive hollyhock, using potyvirus group-specific forward (potyvirid primer 2) and reverse (potyvirid primer 1) primers that amplified a 3 ' terminal 1800-bp fragment including part of the nuclear inclusion $b$, complete coat protein region, and 3' untranslated region (Gibbs et al. 1997; Parrella et al. 2015). The purified PCR products were cloned into the vector pMD18-T. Three clones were sequenced for each sample. Nucleotide sequence comparisons revealed the $3^{\prime}$ terminal portion of the genome of the virus infecting hollyhock (GenBank Accession No. KX426562.1 and KX426563.1) shared 88\% 90\% nucleotide and 93\% 94\% deduced amino acid sequence identity with previously reported Malva vein clearing virus (MVCV) sequences (FJ561293.1, FJ539084.1, EU884405.1, MN116683.1 and KX462994.1). Nucleotide sequence identity was $99.67 \%$ between KX426562.1 and KX426563.2. Phylogenetic analysis of the coat protein amino acid sequence revealed that Beijing isolates clustered with other MVCV isolates and had a close relationship with Italian isolates DS-Ba-01 and Napoli, confirming that the virus infecting hollyhock plants was $\mathrm{MVCV}$, previously reported in other regions of China (e.g., Wang et al. 2020). To our knowledge, this is the first report of MVCV infecting hollyhock plants in Beijing, China.

\section{Declarations}

Ethical approval I comply with ethical standards of the journal of plant pathology. I declare that the submitted manuscript has no potential conflicts of interest with any person or organization. Research work in the manuscript does not involve any human or animal testing. Data are presented in the manuscript or deposited in publicly available repositories (DNA and RNA sequences).

\section{References}

Gibbs A, Mackenzie A (1997) A primer pair for amplifying part of the genome of all potyvirids by RT-PCR. J Virol Methods 63:9-16

Parrella G, Nappo AG, Delecolle B (2015) Cytopathology, biology and molecular characterization of two Italian isolates of Malva vein clearing virus. Plant Science Today 2:69-73

Wang D, Cui L, Pei Y, Ma Z, Shen S, Long D, Li L, Niu Y (2020) Characterization of a strain of Malva vein clearing virus in Alcea rosea via deep sequencing. Plant Pathol J 36:468-475

Publisher's Note Springer Nature remains neutral with regard to jurisdictional claims in published maps and institutional affiliations.

Meisheng Wei

xsms2013@163.com

1 Institute of Plant Inspection and Quarantine, Chinese

Academy of Inspection and Quarantine, Beijing 100176,

China 